\title{
FERNANDO GALEMBECK: 70 ANOS!
}

A vida nos reserva inúmeras surpresas. Ao participar deste Editorial, certamente, estamos frente a uma delas. Uma surpresa que nos coloca, a todos, num contexto de grande alegria, orgulho e satisfação.

Uma alegria que se concretiza na possibilidade de homenagearmos o Prof. Fernando Galembeck, um dos maiores químicos brasileiros que completa 70 anos em plena atividade.

Nascido em São Paulo, no bairro da Bela Vista, foi um menino urbano, criado dentro das limitações e vantagens da cidade grande, mas com direito à liberdade do mato e da praia nas férias. Estudou (muito) no Colégio Santo Alberto e no Liceu Pasteur. Teve excelentes professores de Ciências. Este fato e o trabalho desde os onze anos no laboratório farmacêutico de seu pai determinaram o seu interesse pela Química ${ }^{1}$.

Este momento especial também abre a possibilidade dos pesquisadores mais jovens conhecerem o Prof. Galembeck e o terem presente na memória coletiva da Química brasileira. Devemos lembrar que o reconhecimento do valor do outro, infelizmente, não é prática muito comum em nossa sociedade, daí a importância e oportunidade deste Editorial.

Talvez a força-dirigente - expressão tão do agrado dos químicos - para nos lançarmos neste editorial-homenagem tenha sido o fato de termos rememorado o grande trabalho de Galembeck à frente do PADCT (programa que mudou a cara da química brasileira), as suas iniciativas enquanto Presidente da SBQ, o seu papel fundamental no diálogo com as empresas químicas brasileiras, a coordenação do primeiro documento-base para que a nanociência e a nanotecnologia viessem a fazer parte da agenda científica nacional e, mais recentemente, o exitoso programa " $\mathrm{pH}$ do Planeta", um dos pontos altos da comemoração do Ano Internacional da Química 2011, cujos resultados foram elogiados em vários relatórios internacionais. Não somente por isso, Química Nova quer deixar marcado indelevelmente no tempo o reconhecimento a uma personalidade que deu, e continua dando, contribuições substantivas para a ciência, tecnologia e inovação em nosso país.

Os muitos anos de convivência com ele, não só fez crescer nossa admiração, não apenas pelo seu trabalho como pesquisador de alto nível, de longa e criativa carreira, professor, orientador, administrador, formulador de políticas para a ciência e tecnologia brasileiras ${ }^{2}$, mas também pelo Homem Galembeck, alguém dono de uma dedicação inquebrantável ao trabalho, e uma crença profunda de que sempre é possível sermos cada vez melhores.

Dono de uma altíssima capacidade de observação de "longa, média e curta distância" e de uma intuição científica privilegiada, não é difícil encontrar Galembeck nos finais de semana preguiçosos de Barão Geraldo, em meio às laranjeiras, limoeiros, goiabeiras, palmeiras, bananeiras e cacaueiros, cuidando das podas, da adubação, das pragas, do reconhecimento dos novos brotos, fazendo uso de técnicas amigáveis desenvolvidas por ele mesmo. Ficamos imaginando que muitas de suas ideias sobre ciência, tecnologia e inovação devem ter se manifestado neste urbano "pomar secreto". Sob pena de não errar, não temos dúvida de que a agricultura é a sua segunda grande paixão científica.

Em vários momentos, nestas duas décadas, tivemos oportunidade de vivenciar com Galembeck duras batalhas públicas, e en petit comité, onde interesses legítimos da Química brasileira estavam em jogo. Em todas estas ocasiões, sempre tivemos, proferidas por ele, palavras fortes, seguras, altivas, consequentes e preditivas que levaram a vários resultados importantes para a nossa comunidade e muito do prestígio que desfruta a Química brasileira neste momento.

Muito ainda será escrito e falado sobre o Prof. Fernando Galembeck e tudo, certamente, nunca será demais. Afinal de contas ele é o único químico brasileiro a ter em sua vasta galeria de reconhecimentos dois dos mais importante prêmios brasileiros: $\mathrm{o}$ "Prêmio Almirante Álvaro Alberto para a Ciência e Tecnologia" (CNPq), em 2007, e o Prêmio Anísio Teixeira (CAPES), em 2011, ambos entregues pela Presidência da República.

Uma palavra final. O Prof. Galembeck é uma notável referência para as novas gerações de químicos e pesquisadores brasileiros, não somente pelas suas numerosas e diversificadas realizações. Para além delas, identifica-se claramente sua enorme crença no conhecimento, na dedicação ao trabalho, na disposição e disponibilidade para ensinar, na simplicidade e no seu amor incondicional pelo país e a pela Química, que acabaram por se transformar nas suas pedras de toque.

Bravo! Bravo! Professor Fernando Galembeck!

Oswaldo Luiz Alves (UNICAMP)
Jailson B. de Andrade (UFBA)
Angelo da C. Pinto (UFRJ)
Ex-Presidentes da $S B Q$

\section{REFERÊNCIAS}

1. http://www.abc.org.br/resultado.php3?codigo=fernagal

2. http://buscatextual.cnpq.br/buscatextual/visualizacv.do?id=K4787937A7 